C2020. Licensed under the Creative Commons Attribution-NonCommercial-NoDerivatives

4.0 International http://creativecommons.org/about/downloads

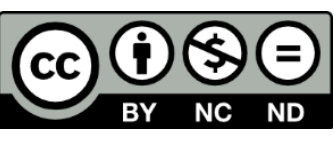

This is not the version of record. The full version can be found at https://doi.org/10.1016/i.scitotenv.2020.141755 


\section{The removal of tetracycline from water using biochar produced from agricultural discarded material}

John Hoslett ${ }^{1}$,Heba Ghazal ${ }^{2}$, Evina Katsou ${ }^{1}$, and Hussam Jouhara ${ }^{1, *}$

${ }^{1}$ Brunel University London, College of Engineering, Design and Physical Sciences, Kingston Lane, Uxbridge UB8 3PH, United Kingdom

${ }^{2}$ Kingston University, School of Pharmacy and Chemistry, Kingston Upon Thames KT1 2EE, United Kingdom

*Corresponding Author: hussam.jouhara@brunel.ac.uk

Figure 1 - Schematic drawing of pyrolysis reactor used in this study (Jouhara et al., 2018) ...9

Figure 2 - SEM image of food/garden waste biochar, magnification: 1000x, electron beam energy: $10.00 \mathrm{kV}$ .14

Figure 3 - EDAX spectrum ( $y=$ counts $x=X$-ray energy $(e V)$ of food/garden waste biochar, magnification: 1000x, electron beam energy: 10.00kV 14

Figure 4-FTIR spectrum for biochar derived from food scraps and plant trimmings..... 16

Figure 5 - Raman spectrum for biochar derived from food scraps and plant trimmings.......16

Figure 6 -Experimental Kinetic data plotted with Elovich model (A), and isothermal data (B)

Figure 7 - Intraparticle diffusion model for the adsorption of tetracycline on biochar with multilinearity in concentrations of $40 \mathrm{mg} / \mathrm{l}$ and above displayed by blue and red lines

Table 1 - Kinetic parameters of tetracycline adsorption on biochar. .19

Table 2 - The adsorption isotherms and the $R^{2}$ values .20 
Table 3 - The production parameters of some biochars, with experimental conditions and tetracycline adsorption for comparison with this study .25

\section{Abstract}

An issue of significant importance worldwide is the contamination of water with antibiotics giving rise to antibiotic resistance in the environment. Antibiotics such as tetracycline are widely used in agriculture, as such they can pollute water courses, providing a means by which environmental bacteria can evolve antibiotic resistance genes. Biochar can form part of a solution as it is a well-known adsorbent. This material can be efficient in the adsorption of a wide range of pollutants and is inexpensive. An innovative heat pipe reactor was used to produce biochar from excess food and garden materials. This biochar was characterised using scanning electron microscopy with energy dispersive X-ray analyser (SEM-EDAX), Fourier transform infrared (FTIR) spectroscopy and Raman spectroscopy. The biochar produced had an adsorption capacity between $2.98 \mathrm{mg} / \mathrm{g}$ and $8.23 \mathrm{mg} / \mathrm{g}$ for initial tetracycline concentrations of $20 \mathrm{mg} / \mathrm{l}$ and $100 \mathrm{mg} / \mathrm{l}$, respectively. The Freundlich isotherm provided the best fit to the experimental data. Kinetics examination revealed a rapid adsorption of tetracycline during the initial stages. The Elovich equation fitted the experimental data well. This adsorbent could therefore be produced at the site of an agricultural enterprise through the pyrolysis of agriculture waste and then used to reduce the infiltration of antibiotics into the environment.

\section{Keywords}

Adsorption, Antibiotics, Biochar, Pyrolysis, tetracycline 


\section{Introduction}

Antibiotics were one of the most important discoveries in the last century and have since been produced and used on a vast scale to combat disease in both animals and humans. The use of antibiotics has dramatically increased quality of life globally, resulting in a culture of over-prescription and improper use of antibiotics. Exposure of bacteria to antibiotics causes the evolution of antibiotic resistance genes (ARGs) in bacteria, thus rendering antibiotics less effective in the future (Wencewicz, 2019). Once these ARGs have developed in bacteria, they can then be horizontally transferred to other bacteria, increasing antibiotic resistance in bacterial communities even without the presence of antibiotics (Strugeon et al., 2016).

This is a matter of global importance as antibiotic resistant bacteria (ARB) can evolve from elevated concentrations of antibiotics in the environment. Antibiotics are used to treat and prevent infections in animals as well as humans. Increased antibiotic resistance can therefore threaten food security, meaning that ARB proliferation threatens the livelihoods of agricultural workers, as well as the lives of the greater population. Thus, it is of vital importance that antibiotics be removed from contaminated water streams as close to the point of entry to the environment as possible.

Tetracycline is one of the most widely used antibiotics in both animal and human treatment, and as such is found in surface water, ground water, sludge and sediments (Mosaleheh and Sarvi, 2020). It is used in animal husbandry due to its broad spectrum and low cost (Chen et al., 2019). It is also used as growth promoters in the livestock industry despite this use being prohibited in many countries.

Tetracycline is often removed from aqueous environments using adsorption techniques. Other removal processes include ozonation, and photocatalysis (Valério et al., 2020). In 
ozonation tetracycline removal takes place either through direct oxidation of organic compounds by ozone molecules, or through the production of hydroxyl radicals that are able to react with most organic compounds (Gómez-Pacheco et al., 2011). In photocatalysis a similar process occurs, where hydroxy radicals are produced at the interface between a photocatalytic material and water, these radicals then react with organic compounds (Yahiat et al., 2011). The removal processes in ozonation and photocatalysis are different and more complicated compared to adsorption techniques.

Desalination is another treatment method which could potentially remove tetracycline from water. This treatment method however is mostly used for saline and brackish water sources, and is rarely used for contaminated freshwater sources where other treatment methods are more applicable (Elsaid et al., 2020a). Graphene is an interesting emerging material in water treatment, where it can be used as an electrode material to reduce concentrations of organic contaminants in water, including freshwater (Olabi et al., 2020). However, graphene is a difficult material to produce, the focus of this article being on in situ production and use of water treatment materials in order to reduce tetracycline concentrations closer to the point of entry into the environment. For this reason, graphene electrode microbial fuel cells are best suited to centralised water treatment systems where they can be more economically operated and maintained. Energy input is required for ozonation, photocatalysis, desalination and microbial fuel cells, with trained personnel also needed to maintain and operate such systems. Desalination requires energy input either to overcome the osmotic pressure difference across a membrane in reverse osmosis, or to heat the water in the various thermally driven desalination processes (Elsaid et al., 2020b). Biomass produced by an agricultural enterprise could be used as a fuel to produce heat and electricity for desalination processes. Agriculture already makes use of anaerobic digestion to produce biogas for energy 
production (Olabi, 2010), therefore using this on site to power desalination is feasible. However, it could result in a loss in income where energy produced using biogas can be sold back to energy suppliers. Whilst anaerobic digestion can convert materials such as manure and slurry from animals into a useful energy resource, some agricultural waste materials are not broken down as readily by the anaerobic digestion process. These typically contain hemicellulose, cellulose and lignin, which have lower rates of hydrolysis in anaerobic digestion, limiting these materials' application in anaerobic digestion (Li et al., 2018). Pyrolysis is an attractive method for treating these materials, resulting in the production of syngas and bio-oil, which can both be used for energy production, potentially including district energy systems (Mahmoud et al., 2020). Biochar is also produced; this is a highly versatile material with many uses. A biochar application that has received significant research interest in the last 30 years is its use as an adsorbent material, where it is able to remove a wide array of contamination including tetracycline (Yu et al., 2020; Zeng et al., 2019). The typical removal mechanisms in biochar include $\pi$ orbital interactions, and electrostatic interactions (Tran et al., 2020). Modified biochar can also result in oxidative degradation of tetracycline (Alatalo et al., 2019). Adsorption is an attractive and simple removal technique in this regard as it does not necessarily require a direct energy input to function as it is possible to utilise adsorbents in easily operated gravity feed columns.

Biochar is a material produced through the pyrolysis of carbonaceous material such as plastics, tyres, paper, wood and other forms of biomass. In recent years biochar produced from different feedstocks has been extensively researched for its use as an adsorbent material of many different pollutants. A feedstock which has seldom been used to produce adsorbents in literature are mixed discarded materials (MDM) using the mixed food/organic fraction of this material. The results of previous studies have shown that copper and 
methylene blue were removed up to $6.28 \mathrm{mg} / \mathrm{g}$ and $7.26 \mathrm{mg} / \mathrm{g}$ respectively by biochars derived from this material in a novel heat pipe-based pyrolysis reactor (Hoslett et al., 2020, 2019). It is foreseeable that an agricultural enterprise could produce biochar adsorbents from their own by-products which would remove antibiotics residues. This research will seek to explore potential cradle-to-grave routes for biomass pyrolysis products in pollutants removal from aqueous solutions in line with the principles of Circular Economy.

As it is, there is already a great deal of research regarding tetracycline adsorption, using various adsorbents. The majority of the studies apply pyrolysis temperatures above $500{ }^{\circ} \mathrm{C}$, and typically utilise feedstocks such as sewage sludge, manure, agricultural waste and lignocellulosic materials such as wood (Jang et al., 2018; Yan et al., 2020; Zhang et al., 2019). The high pyrolysis temperatures can result in the production of polycyclic aromatic hydrocarbons (PAHs) and dioxins, which are harmful to the environment and can be toxic to humans. Feedstock is much more influential in the production of PAHs and dioxins at pyrolysis temperatures below $500{ }^{\circ} \mathrm{C}$, therefore the PAHs and dioxins can be reduced by avoiding certain feedstocks (Mohseni-Bandpei et al., 2019; Yang et al., 2019). Thus, this article focuses on the use of a pyrolysis temperature of $300^{\circ} \mathrm{C}$ as it leads to the production of decreased amounts of PAHs.

Furthermore, activation procedures are often implemented to improve the biochar quality. Activation processes often target the increase in porosity, surface area and surface functional groups in the biochar (Choudhary et al., 2020; Jang and Kan, 2019a; Kwak et al., 2019; Sajjadi et al., 2020). Tetracycline removal and adsorption can be improved by the activation of biochars with other chemicals, such as persulfate which can release radicals, these radicals then react with tetracycline and lead to its degradation (Chen et al., 2020). 
Activation procedures improve the characteristics of biochar, however their replicability under different economic circumstances is questionable. They either require specialist equipment such as sonication, access to chemicals, as well as specialist training in order to operate. Such processes could be implemented but would represent a significant expense in terms of materials and personnel (Joseph et al., 2019). Therefore, this study proceeds with an approach that is conducive with the use of a heat pipe reactor by an adequately trained operator. The process produces biochar using a single stage pyrolysis process at a temperature of $300{ }^{\circ} \mathrm{C}$ in a heat pipe pyrolysis reactor. The objective of this study is to prove that biochar produced in a novel heat pipe reactor at temperatures of $300{ }^{\circ} \mathrm{C}$ can remove tetracycline from aqueous solutions, without the need for complicated and/or costly activation procedures and equipment.

\section{Materials and Methods}

\subsection{Materials}

Tetracycline hydrochloride $\geq 95 \%$ (European Pharmacopoeia HPLC assay) (CAS:64-75-5, $\left.\mathrm{C}_{22} \mathrm{H}_{24} \mathrm{~N}_{2} \mathrm{O}_{8} \cdot \mathrm{HCl}\right)$ was purchased from Sigma-Aldrich and stored in a freezer. Titripur $0.5 \mathrm{M}$ sodium hydroxide (CAS:1310-73-2, $\mathrm{NaOH}$ ) and Titripur 0.5M sulfuric acid (CAS: 7664-93-9, $\left.\mathrm{H}_{2} \mathrm{SO}_{4}\right)$ were purchased from Sigma-Aldrich. Ultrapure water $(18.2 \mathrm{M} \Omega \mathrm{cm})$ was drawn from a Milli-Q water purification system. Domestic food scraps and plant trimmings were collected as precursor material to mimic discarded materials expected from an agricultural enterprise. Agricultural waste also includes plant trimmings and other materials such as vegetable and fruit peels (De Corato, 2020; Kadhom et al., 2020), making it similar in composition to those found in domestic garden settings. 


\subsection{Biochar production}

Biochar was produced using mixed food scraps and plant trimmings as a precursor material. A pilot scale heat pipe reactor was used in this study to pyrolyze the feedstock, the schematic of which can be seen in Figure 1. The heat pipe reactor was heated to $300{ }^{\circ} \mathrm{C}$ and held at this temperature for $12 \mathrm{~h}$, before being allowed to cool. The biochar was removed from the system once the reactor had cooled to ambient temperature.

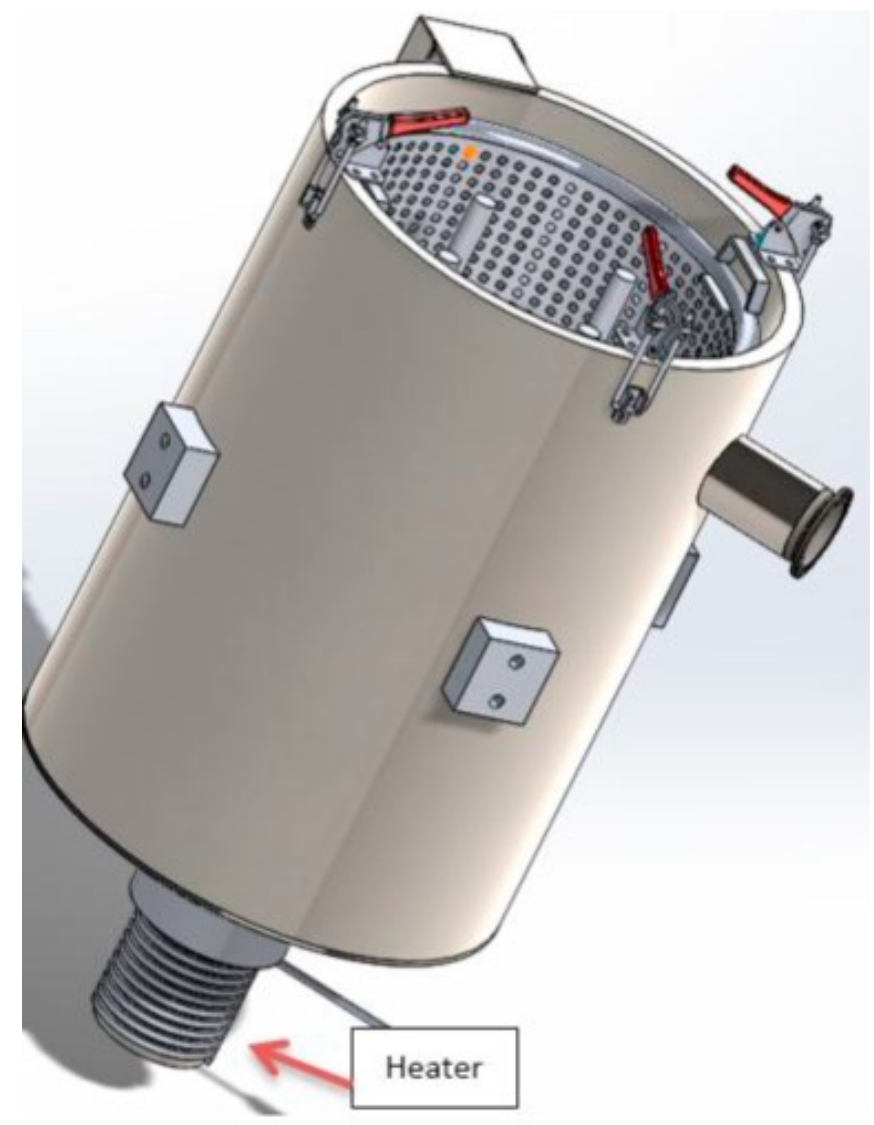

Figure 1 - Schematic drawing of pyrolysis reactor used in this study (Jouhara et al., 2018)

\subsection{Biochar characterisation}

Biochar was characterised using Scanning Electron Microscopy (SEM), Energy Dispersive X-ray Analysis (EDAX), Fourier Transmission Infra-Red spectroscopy (FTIR), and Raman spectroscopy. The SEM analysis was conducted using a Zeiss Leo scanning electron microscope. The electron energy was set to 10kV. EDAX was conducted on the biochar after 
the SEM image was collected. FTIR was conducted using a Perkin Elmer FTIR to determine functional groups present on the biochar. Raman shift spectroscopy was conducted with shift spectra between $0-2800 \mathrm{~cm}^{-1}$ with a $514 \mathrm{~nm}$ wavelength laser. This was conducted to analyse the carbon structures within the biochar using a Renishaw Raman microscope.

\subsection{Batch adsorption experiments}

A stock solution of $1000 \mathrm{mg} / \mathrm{l}$ was produced through the dissolution of $1.082 \mathrm{~g}$ of tetracycline hydrochloride in $1 \mathrm{~L}$ of Milli-Q ultrapure water. This stock solution was diluted to produce the desired concentrations of tetracycline in the kinetic and isotherm batch experiments. Batch adsorption experiments were carried out at room temperature. The initial $\mathrm{pH}$ of each adsorbate tetracycline solution was adjusted to 7 to provide a neutral $\mathrm{pH}$, with $0.1 \mathrm{M} \mathrm{H}_{2} \mathrm{SO}_{4}$ and $0.1 \mathrm{M} \mathrm{NaOH}$ prior to the addition of the biochar. This $\mathrm{pH}$ was selected due to its similarity to natural $\mathrm{pH}$ levels. For all experiments, $2.5 \mathrm{~g}$ of biochar was added to $500 \mathrm{ml}$ of adsorbate solution. This solution was stirred at $360 \mathrm{rpm}$ for up to $6 \mathrm{~h}$.

The amount of tetracycline adsorbed onto biochar at time $\mathrm{t},(\mathrm{mg} / \mathrm{g})$ was determined using equation 1. The assumption that makes the use of this equation possible is considering the concentration of biochar is homogenous throughout the experiment. Therefore, when a sample is taken, tetracycline, as well as some biochar are removed from the experiment. This equation accounts for the reduction in tetracycline amounts caused by sampling.

$q_{t, c}=\frac{C_{i} * V_{i}-\left(C_{t} *\left(V_{i}-\sum_{t=0}^{t=t} V_{S}\right)+\sum_{t=0}^{t=t, p} C_{t, p} V_{s}\right)}{D *\left(V_{i}-\sum_{t=0}^{t=t} V_{s}\right)}-q_{t, p} V_{s} D$

Where $q_{t, c}$ and $q_{t, p}$ are the current adsorption and adsorption to biochar of the previous sample respectively $\left(\mathrm{mg} \mathrm{g}^{-1}\right) . \mathrm{C}_{\mathrm{i}}, \mathrm{C}_{\mathrm{t}}$ and $\mathrm{C}_{\mathrm{t}, \mathrm{p}}(\mathrm{mg} / \mathrm{L})$ are the liquid phase tetracycline concentrations at $t=0, t=t$ and $t=t, p$ (mins) respectively, where $t, p$ is the time of the previous sample (mins). $V_{i}$ is the initial volume of the solution $V_{s}$ is the volume of one sample (I), and $D$ 
is adsorbent dosage $(\mathrm{g} / \mathrm{l})$. The solid phase equilibrium concentration of tetracycline $\mathrm{q}_{\mathrm{e}}(\mathrm{mg} / \mathrm{g})$ is determined when $C_{t}=C_{e}$.

\subsection{Adsorption Kinetic experiments}

Experiments to determine the kinetic behaviour were conducted between times of $0-$ $360 \mathrm{~min}$, using tetracycline concentrations of $0-100 \mathrm{mg} / \mathrm{l}$, under the conditions described previously.

The pseudo first order (PFO), pseudo second order (PSO), and Elovich models are displayed in equations 2, 3 and 4 respectively. The non-linear kinetic models were modelled against the experimental data using SAS University edition software. Non-linear regression using the Gauss-Newton method was conducted in order to determine which of the PFO, PSO, or Elovich model best describe the adsorption of tetracycline to biochar. The data was then plotted on a linear scale to determine whether there was multi-linearity within the intraparticle diffusion model, and therefore multiple adsorption mechanisms.

$$
\begin{aligned}
& q_{t}=q_{e}\left(1-e^{-k_{1} t}\right) \\
& q_{t}=\frac{k_{2} q_{e}^{2} t}{1+k_{2} q_{e} t} \\
& q_{t}=\frac{1}{\beta} \ln (1+a \beta t) \\
& q_{t}=k_{i} t^{1 / 2}+C
\end{aligned}
$$

Where $\mathrm{q}_{\mathrm{t}}(\mathrm{mg} / \mathrm{g})$ is the adsorption at time $\mathrm{t}$ (mins), $\mathrm{q}_{\mathrm{e}}(\mathrm{mg} / \mathrm{g})$ is the adsorption at equilibrium, $k_{1}$ is the pseudo first order rate constant $\left(\min ^{-1}\right), k_{2}$ is the pseudo second order rate constant (g.mg $\mathrm{min}^{-1}$ ), $\beta$ (g.mg $\mathrm{m}^{-1}$ ) is the surface coverage and activation energy constant, $\alpha$ (mg.g $\left.{ }^{1} \cdot \mathrm{min}^{-1}\right)$ is the initial adsorption rate, $\mathrm{k}_{\mathrm{i}}\left(\mathrm{mg} \cdot \mathrm{g}^{-1} \cdot \mathrm{min}^{-1 / 2}\right)$ is the rate constant of the intraparticle diffusion model, and C $\left(\mathrm{mg} . \mathrm{g}^{-1}\right)$ is the intercept relating to the amount of tetracycline removed by rapid initial adsorption. 


\subsection{Adsorption Isotherm experiments}

Experiments to determine isothermal behaviour of biochar were conducted using the same conditions as described previously.

The isotherm models analysed are the Langmuir, Freundlich and Sips models shown in equations 6, 7 and 8 respectively. These were modelled with the experimental data using SAS University edition. Gauss-Newton non-linear regression was also carried out on these equations to determine which of the models best describes the isothermal behaviour of tetracycline adsorption to biochar.

$$
\begin{aligned}
& \mathrm{q}_{\mathrm{e}}=\frac{\mathrm{C}_{\mathrm{e}} \mathrm{k}_{\mathrm{L}} \mathrm{q}_{\mathrm{m}}}{1+\mathrm{k}_{\mathrm{L}} \mathrm{C}_{\mathrm{e}}} \\
& \mathrm{q}_{\mathrm{e}}=\mathrm{k}_{\mathrm{f}} \mathrm{C}_{\mathrm{e}}{ }^{1 / n} \\
& \mathrm{q}_{\mathrm{e}}=\frac{\mathrm{k}_{\mathrm{s}} \mathrm{q}_{\mathrm{m}} \mathrm{C}_{\mathrm{e}}^{\mathrm{s}}}{1+\mathrm{k}_{\mathrm{s}} \mathrm{C}_{\mathrm{e}}^{\mathrm{s}}}
\end{aligned}
$$

Where $\mathrm{q}_{\mathrm{e}}\left(\mathrm{mg} \mathrm{g}^{-1}\right)$ is the adsorption at equilibrium, $\mathrm{C}_{\mathrm{e}}\left(\mathrm{mg} \mathrm{l}^{-1}\right)$ is the concentration at equilibrium, $k_{L}\left(l \mathrm{mg}^{-1}\right)$ is the Langmuir constant, $\mathrm{q}_{\mathrm{m}}\left(\mathrm{mg} \mathrm{g}^{-1}\right)$ is the maximum adsorption capacity, $\mathrm{k}_{\mathrm{f}}\left(\mathrm{I} \mathrm{g}^{-1}\right)$ is the Freundlich constant, $\mathrm{n}$ is the Freundlich constant that describes the intensity of adsorption to the biochar surface (Saleh et al., 2018), $\mathrm{k}_{\mathrm{s}}$ is the Sips adsorption constant, and s describes the surface heterogeneity as in the Freundlich model (Wang et al., 2020).

\subsection{Statistical analysis}

The Kinetic and isothermal models were analysed using Gauss-Newton non-linear regression. The best model was decided on based upon both the $\mathrm{R}^{2}$ value and Mean squared error (MSE), calculated by equations 9 and 10 respectively.

$$
R^{2}=\left(\frac{n\left(\sum q_{\text {exp }} q_{\text {pred }}\right)-\left(\sum q_{\text {exp }}\right)\left(\sum q_{\text {pred }}\right)}{\sqrt{\left[n \sum q_{\text {exp }}{ }^{2}-\left(\sum q_{\text {exp }}\right)^{2}\right]\left[n \sum q_{\text {pred }}{ }^{2}-\left(\sum q_{\text {pred }}\right)^{2}\right]}}\right)^{2}
$$


$M S E=\frac{1}{n} \sum_{i=1}^{n}\left(q_{\text {exp }}-q_{\text {pred }}\right)^{2}$

Where $\mathrm{n}$ is the number of variables, $\mathrm{q}_{\exp }\left(\mathrm{mg} \mathrm{g}^{-1}\right)$ is the experimentally observed adsorption and $\mathrm{q}_{\text {pred }}\left(\mathrm{mg} \mathrm{g}^{-1}\right)$ is the adsorption as predicted by the respective kinetic or isothermal model.

\section{Results}

\subsection{Characterisation of biochar}

\subsubsection{SEM-EDAX}

Figure 2 shows an SEM image of biochar. The biochar surface in this image is seen to be heterogeneous with features including varying sizes of pores. Additionally, crystal like structures are visible on the surface, with these likely being mineral deposits. These crystals are likely high in potassium since the EDAX analysis in Figure $\mathbf{3}$ shows a strong presence of potassium in the biochar. This elevated level of potassium is expected in the biochar since animal and plant matter contain more potassium than other feedstocks (Novak et al., 2018). Additionally, the biochar shows a large amount of oxygen, this is present due to the pyrolysis temperature used as oxygen is not driven off at $300^{\circ} \mathrm{C}$. 


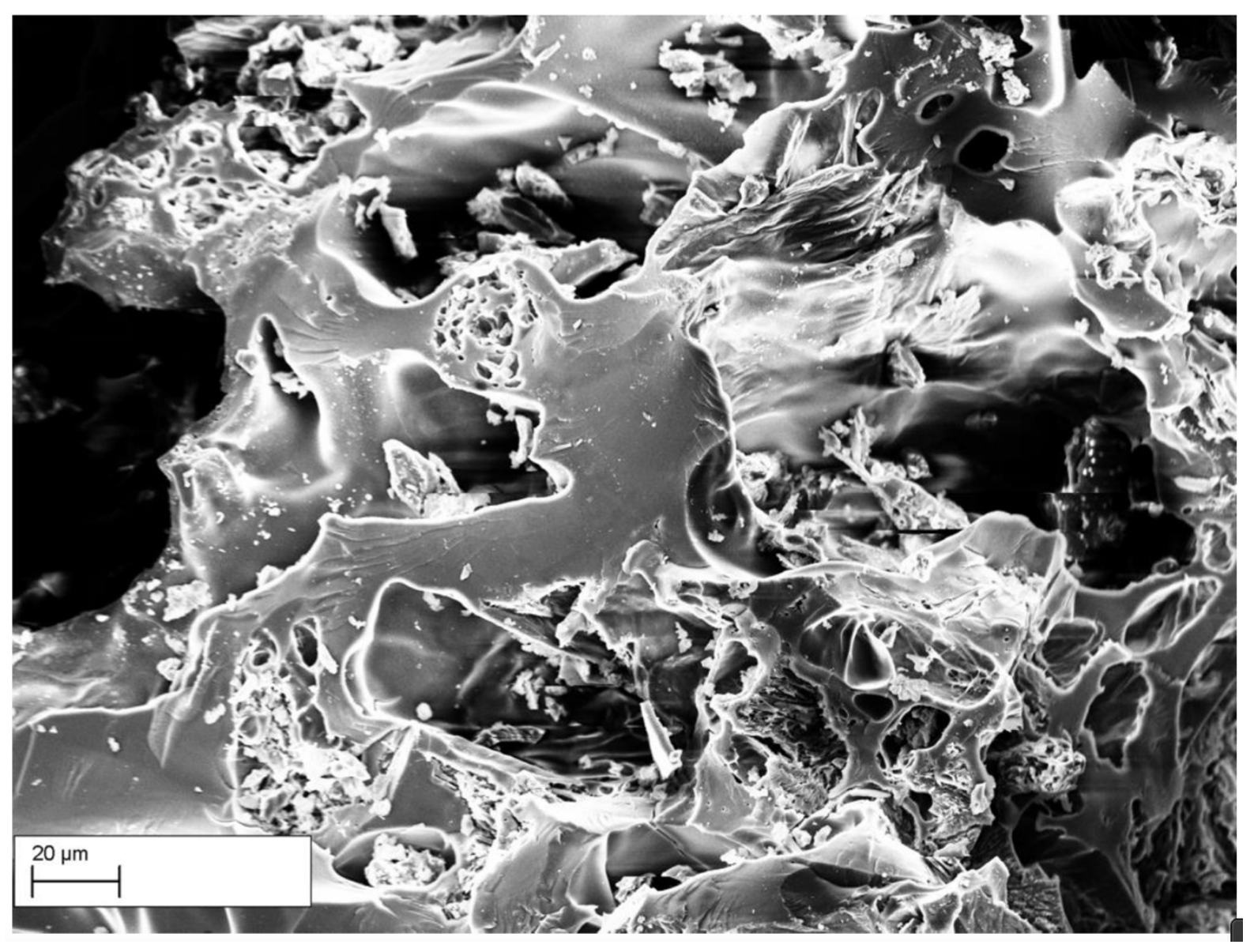

Figure 2 - SEM image of food/garden waste biochar, magnification: 1000x, electron beam energy: 10.00kV

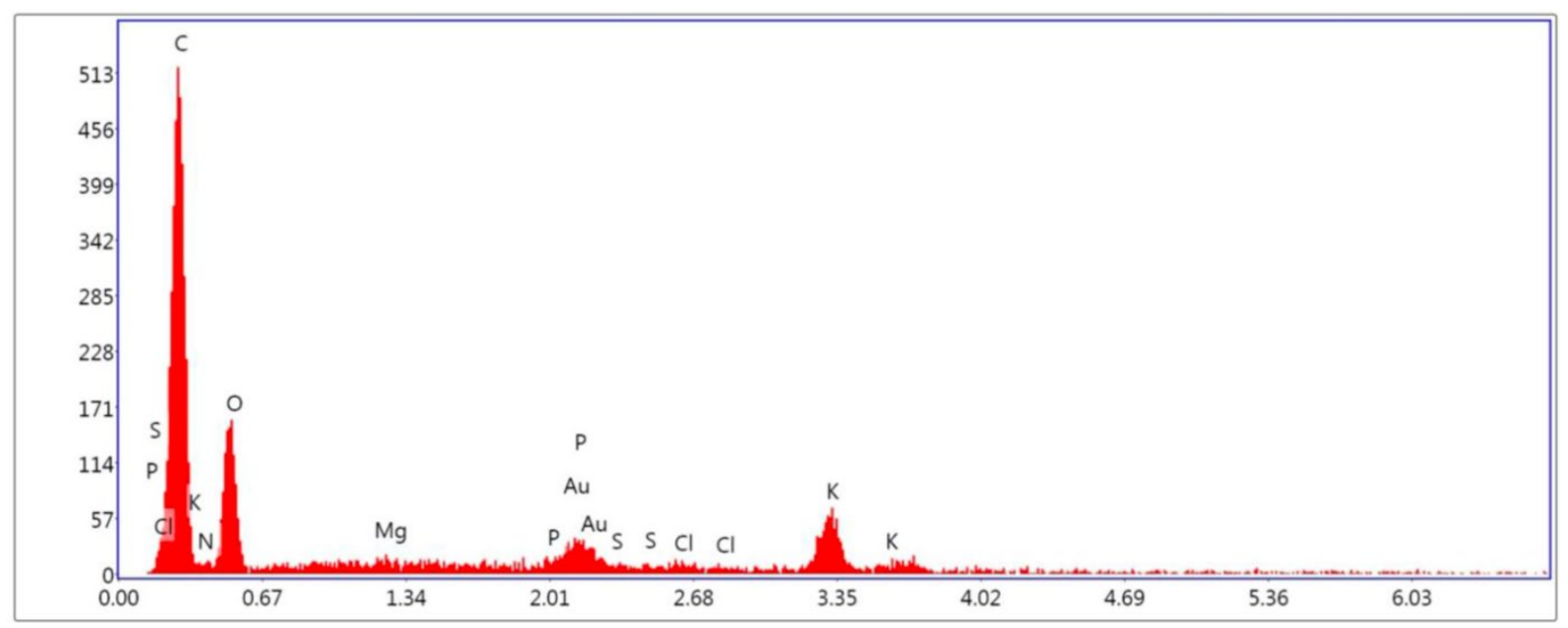

Figure 3 - EDAX spectrum ( $y=$ counts $x=X$-ray energy $(e V)$ of food/garden waste biochar, magnification: 1000x, electron beam energy: $10.00 \mathrm{kV}$ 


\subsubsection{FTIR and Raman spectroscopy}

Figure 4 shows the FTIR spectrum for biochar derived from food scraps and plant trimmings. Absorbance between 3000 and $2800 \mathrm{~cm}^{-1}$ can be attributed to alkane $\mathrm{C}-\mathrm{H}$ stretching but may also be exaggerated by alcohol $-\mathrm{OH}$ stretching. The peaks between $1750 \mathrm{~cm}^{-1}$ and $1500 \mathrm{~cm}^{-1}$ can be associated with stretching of $\mathrm{C}=\mathrm{O}$ bonds, as well as stretching of $\mathrm{C}=\mathrm{C}$ bonds. The absorbance shoulder at $1465 \mathrm{~cm}^{-1}$ is caused by $\mathrm{C}-\mathrm{H}$ bending in methylene groups on the biochar surface. Further evidence of $\mathrm{OH}$ groups is visible from the $\mathrm{OH}$ bending between 1420 and $1330 \mathrm{~cm}^{-1}$. Between 1100 and $900 \mathrm{~cm}^{-1}$ is indicative of secondary and primary alcohol C-O stretching and alkene $\mathrm{C}=\mathrm{C}$ bending. Finally, the multiple peaks between 900 and $700 \mathrm{~cm}^{-1}$ are likely caused by $\mathrm{C}-\mathrm{H}$ bending.

The Raman spectrum in Figure $\mathbf{5}$ shows a mixture between carbon structures, the peak at $1370 \mathrm{~cm}^{-1}$ shows disordered graphitic structures (D), where the peak at $1590 \mathrm{~cm}^{-1}$ shows ordered graphitic structures $(G)$. The intensity of both the $G$ and $D$ peaks show that biochar produced from food and plant material at $300^{\circ} \mathrm{C}$ are a mixture of different carbon structures including sp2 and sp3 hybridization (Yu et al., 2019). The presence of sp-3 orbitals in this case shows the likely presence of carbon with oxygen and hydrogen bonds, indicating the presence of amorphous carbon (Chen et al., 2018). 


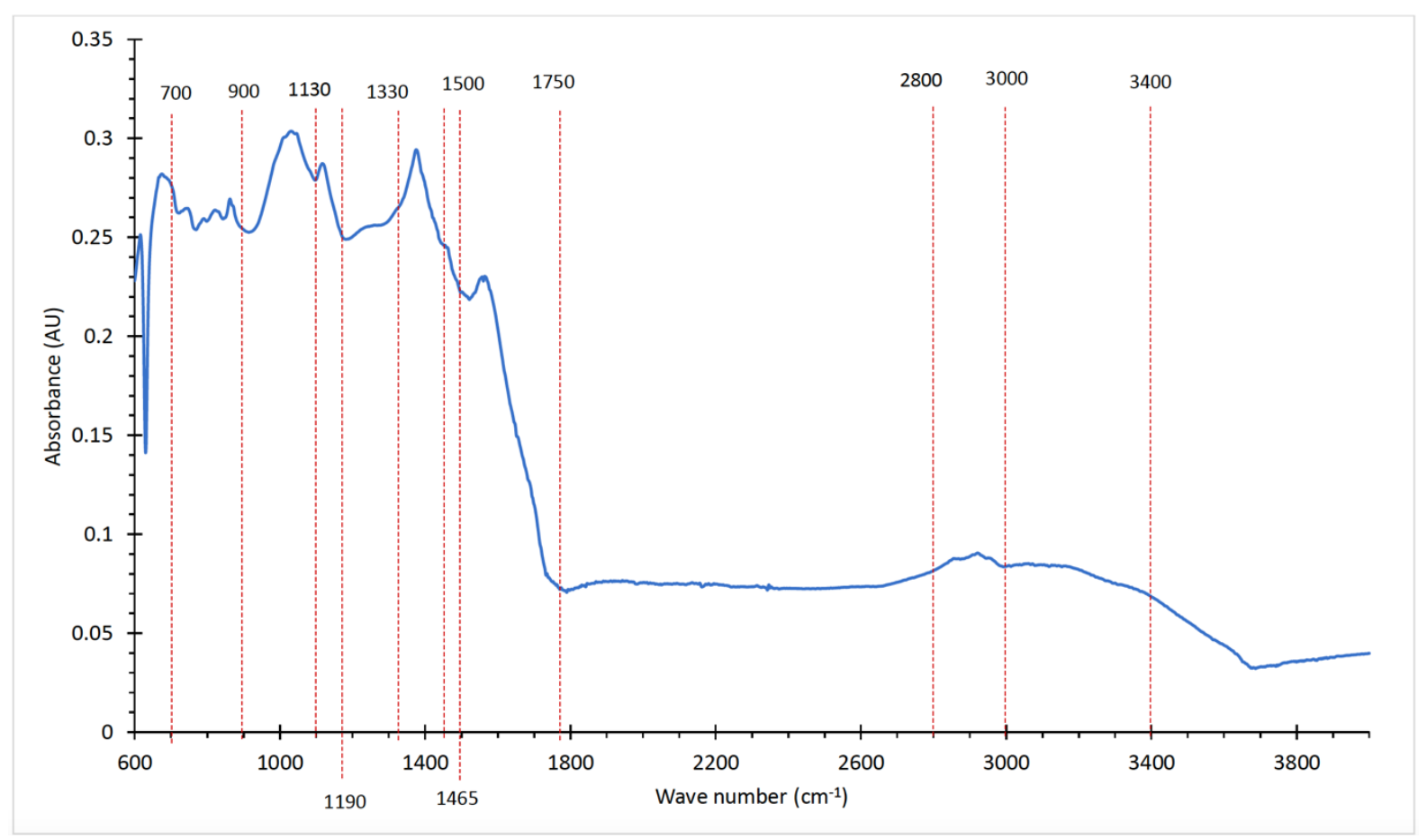

Figure 4 - FTIR spectrum for biochar derived from food scraps and plant trimmings

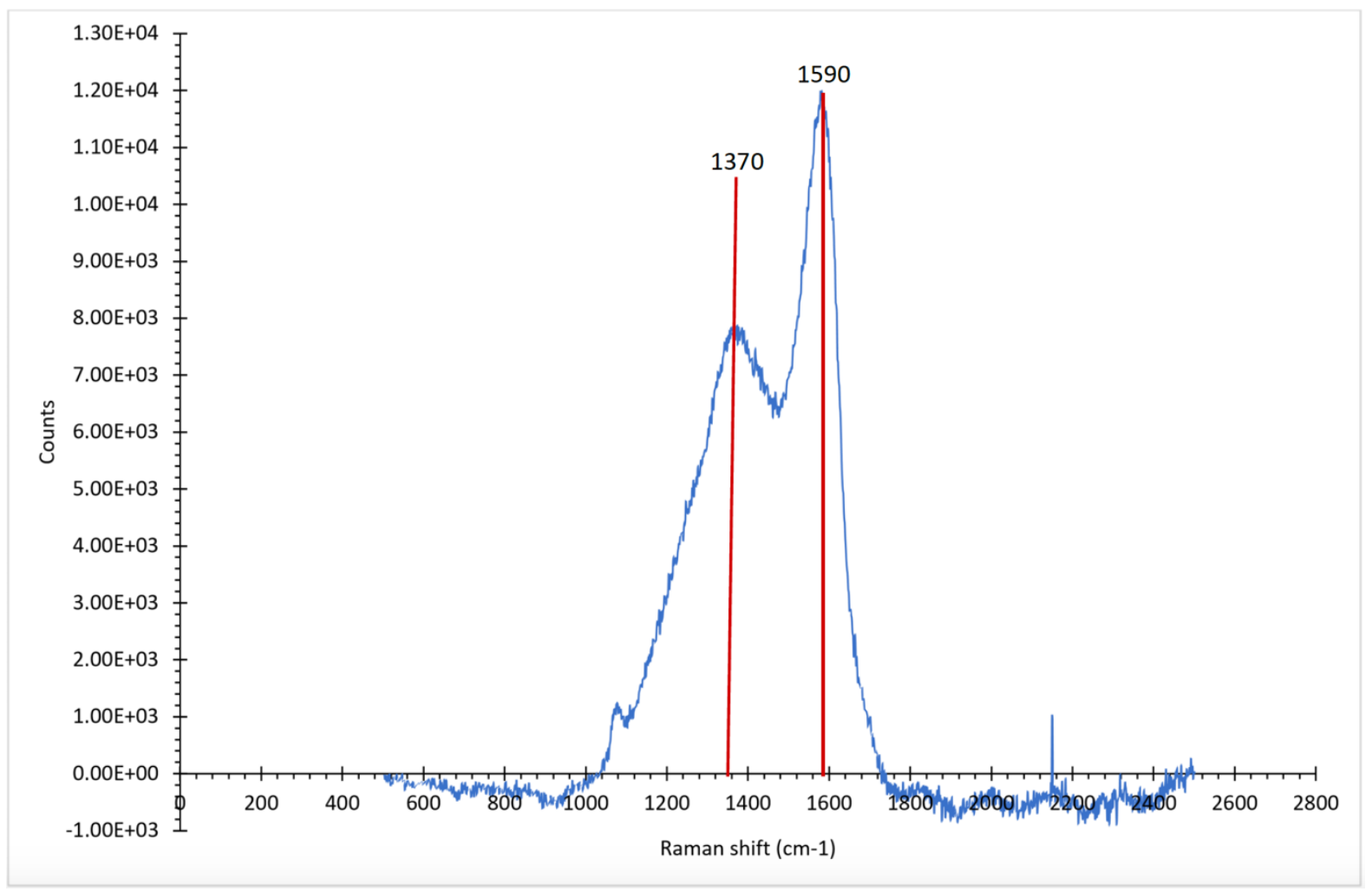

Figure 5 - Raman spectrum for biochar derived from food scraps and plant trimmings 


\subsection{Adsorption Kinetics and Isotherms}

Kinetics studies aim to describe the rate of tetracycline uptake on the biochar. The kinetic parameters are helpful for the prediction of the adsorption rate and provide important information for the modelling of processes. The study of adsorption mechanisms was performed to determine the rate-controlling stage. Thus, the intraparticle diffusion model was compared against the experimental data.

The adsorption kinetic results shown in Figure $6 \mathrm{~A}$ and Table 1 show that the kinetic model fits follow the order Elovich>PSO>PFO. The Elovich model assumes that the surface of the biochar adsorbent is a heterogenous surface, meaning that there are parts of the surface that have more affinity for tetracycline adsorption than others (Wu et al., 2009). The fit for tetracycline adsorption using the Elovich model suggests that tetracycline is strongly associated with the biochar, and the adsorbed tetracycline is thus immobilised (Waiapu Timothy McMillan, 2018). Furthermore, a general trend can be seen that as initial concentration increases, the $\beta$ value decreases, indicating that at higher initial concentrations more adsorption sites are utilized (Jang and Kan, 2019a). The stronger fit of the pseudo second order model over the pseudo first order model shows that the rate of adsorption is determined by chemisorption processes (Zhang et al., 2019). The PFO model describes the diffusion of tetracycline across the liquid film between the aqueous solution and the surface of the biochar (Das and Dash, 2017).

Figure 7 shows the linear display of the intraparticle diffusion model. It can be seen that the regression lines do not pass through the origin. This suggests that intraparticle diffusion does not solely explain the diffusion of tetracycline from the solution into the adsorbent. This indicates that both intraparticle diffusion, and liquid film diffusion control the rate of transfer of tetracycline into the adsorbent (Oyelude et al., 2017). 
The adsorption is rapid at initial stages for all initial concentrations (Tang et al., 2018) due to film diffusion as represented by the PFO model, this is evident as the regression lines do not intercept the origin. This stage is followed by a slowed adsorption where intraparticle diffusion into macropores becomes the rate limiting step (Pan et al., 2017), this is represented by the blue lines in Figure 7 . Lastly the diffusion of tetracycline is slowed further with the diffusion of tetracycline becoming limited by diffusion into smaller meso and micropores, represented by the red lines on the chart.

Figure 6B shows a plot of experimental data with isotherm models. The isotherm constants are summarised in Table 2. The Freundlich model best describes the adsorption of tetracycline to biochar in this study. Freundlich isotherm model assumes that adsorption can be multilayer, whereas the Langmuir model assumes that adsorption takes place in a monolayer fashion. Therefore, it could be concluded that tetracycline adsorbs to biochar derived from food scraps and plant trimmings at low pyrolysis temperatures in a multilayer fashion.

The maximum adsorption capacity was $15.5208 \mathrm{mg} / \mathrm{g}$. In the case of Langmuir isotherm, the dimensionless coefficient $R_{\mathrm{L}}$ value varied between 0 and 1 showing favourable adsorption. The value of $\mathrm{n}$ in the Freundlich model was higher than 1, also confirming favourable adsorption. Figure 6B also shows that the experimental data appears to follow an almost linear relationship, this could potentially be due to the greater influence of partitioning mechanisms at the concentrations studied, these typically follow linear isothermal equations and occur due to the presence of amorphous carbon. From the figure it can be deduced that such a linear equation would not intercept the origin, this shows that both adsorption and partitioning processes are responsible for the removal of tetracycline from aqueous solution by biochar (Waiapu Timothy McMillan, 2018). 


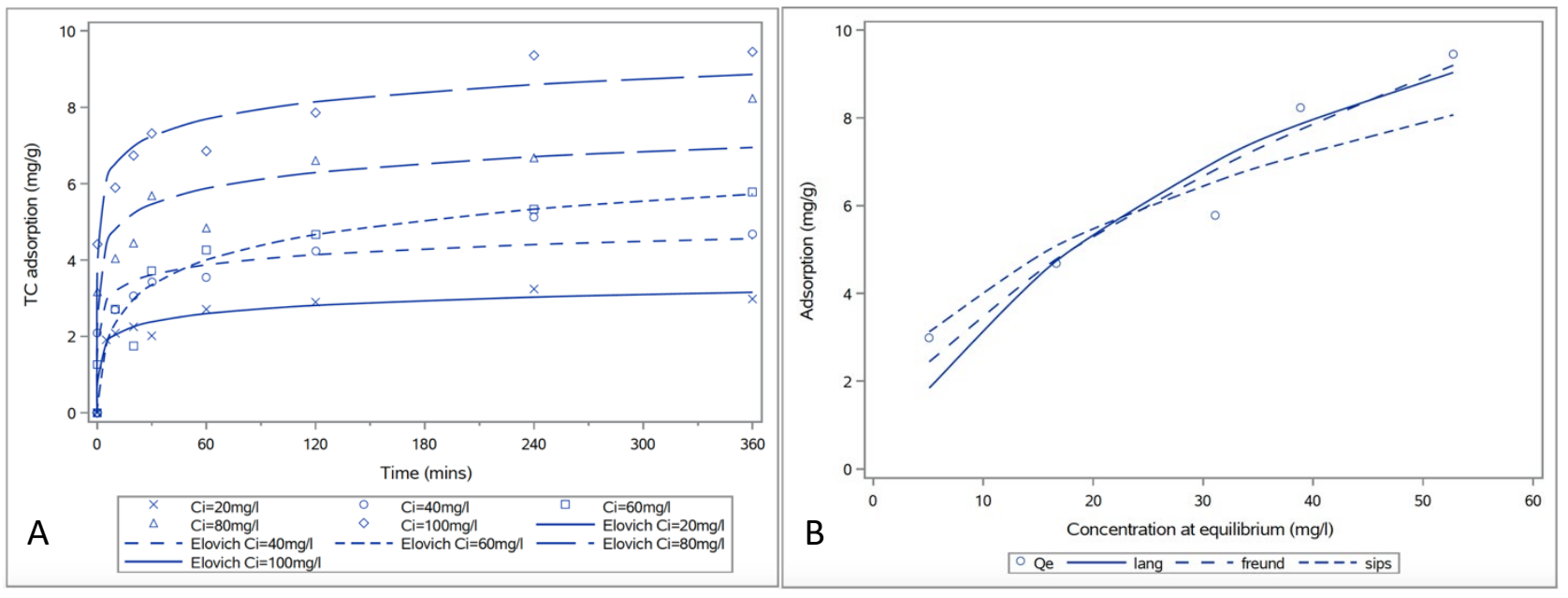

Figure 6 -Experimental Kinetic data plotted with Elovich model (A), and isothermal data (B)

Table 1 - Kinetic parameters of tetracycline adsorption on biochar

\begin{tabular}{llllll}
\hline Initial tetracycline conc. $\left(\mathrm{mg} \mathrm{l}^{-1}\right)$ & 20 & 40 & 60 & 80 & 100
\end{tabular}

\section{Pseudo Second Order}

\begin{tabular}{lccccc}
\hline $\mathbf{k}_{2}$ & 0.0699 & 0.0186 & 0.0128 & 0.0115 & 0.0189 \\
\hline $\mathbf{q}(\mathbf{m g} / \mathrm{g})$ & 3.0417 & 4.9261 & 5.6978 & 7.5359 & 9.0509 \\
& & & & & \\
\hline $\mathbf{R}^{\mathbf{2}}$ & 0.9171 & 0.8438 & 0.9550 & 0.8092 & 0.8102 \\
& & & & & \\
\hline MSE & 0.0904 & 0.6278 & 0.2752 & 1.7827 & 2.7362
\end{tabular}

\section{Pseudo first order}

\begin{tabular}{lccccc}
\hline $\mathbf{k}_{1}$ & 0.1644 & 0.0611 & 0.0516 & 0.0620 & 0.0930 \\
\hline $\mathbf{q e}(\mathbf{m g} / \mathrm{g})$ & 2.7891 & 4.5383 & 5.1964 & 6.8644 & 8.5350 \\
& & & & & \\
\hline $\mathbf{R}^{2}$ & 0.8354 & 0.8062 & 0.9228 & 0.7634 & 0.7765 \\
\hline MSE & & & & & \\
\hline
\end{tabular}

\section{Elovich}

\begin{tabular}{llllll}
\hline $\boldsymbol{\alpha}$ & 13.3634 & 118.8 & 8.2847 & 140.7 & 940.2 \\
\hline $\boldsymbol{\beta}$ & 2.9161 & 2.4674 & 1.5026 & 1.5798 & 1.4347
\end{tabular}




\begin{tabular}{lccccc}
\hline $\mathbf{R}^{\mathbf{2}}$ & 0.9688 & 0.9234 & 0.9761 & 0.8884 & 0.9557 \\
& & & & & \\
\hline MSE & 0.0345 & 0.2054 & 0.1215 & 0.7012 & 0.4341
\end{tabular}

Table 2 - The adsorption isotherms and the $\mathrm{R}^{2}$ values

\begin{tabular}{|c|c|c|c|c|c|c|}
\hline Langmuir & $\mathrm{kL}_{\mathrm{L}}\left(\mathrm{l} \mathrm{mg}^{-1}\right)$ & $\left.\mathrm{qm}, \mathrm{L}_{(\mathrm{mg} \mathrm{g}} \mathrm{g}^{-1}\right)$ & & $\mathbf{R}_{\mathbf{L}}$ & $\mathbf{R}^{2}$ & MSE \\
\hline $\begin{array}{l}\text { Initial } \\
\text { concentrati } \\
(\mathrm{mg} / \mathrm{l})\end{array}$ & & & & & & \\
\hline 20 & 0.0264 & 15.5208 & & 0.6545 & 0.9083 & \\
\hline 40 & & & & 0.4864 & & \\
\hline 60 & & & & 0.3870 & & \\
\hline 80 & & & & 0.3213 & & \\
\hline 100 & & & & 0.2747 & & 0.8424 \\
\hline \multirow[t]{2}{*}{ Freundlich } & $k_{F}\left(l^{-1}\right)$ & $\mathbf{n}$ & & & & \\
\hline & 0.9676 & 1.7607 & & & 0.9403 & 0.5486 \\
\hline \multirow[t]{2}{*}{ Sips } & $\mathrm{ks}\left(\mathbf{l} \mathrm{mg}^{-1}\right)$ & $q_{m}\left(m g ~ g^{-1}\right)$ & $\mathbf{S}$ & & & \\
\hline & 0.0182 & 88.0456 & 0.4318 & & 0.9183 & 0.5811 \\
\hline
\end{tabular}




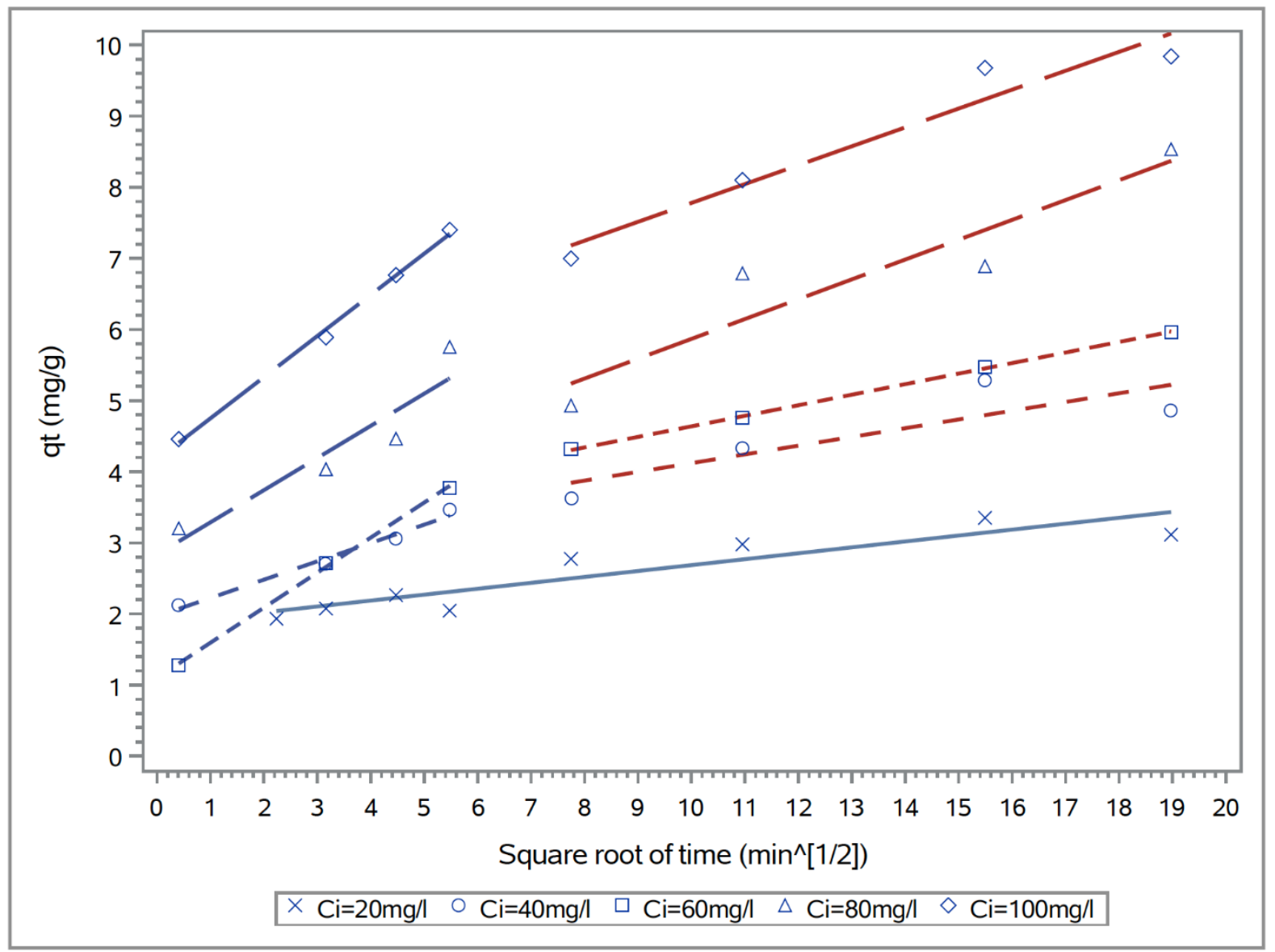

Figure 7 - Intraparticle diffusion model for the adsorption of tetracycline on biochar with multilinearity in concentrations of $40 \mathrm{mg} / \mathrm{l}$ and above displayed by blue and red lines

\section{Discussion}

\subsection{Adsorption Mechanisms}

As shown in the analysis, the biochar produced comprises predominantly carbon and oxygen, with a few traces of minerals, the largest fraction of minerals containing potassium. In addition to the elemental composition the analysis also proves the presence of $\pi$ electron donors where aromatic sp2 groups are shown to exist in the biochar by the Raman and FTIR analyses. The tetracycline molecule has one aromatic ring as well as other $\mathrm{C}=\mathrm{C}$ double bonds, thus, $\pi-\pi$ electron-acceptor-donor (EDA) interactions are the main expected mechanism through which tetracycline is removed from aqueous solution by biochar (Cheng et al., 2020). 
The oxygen and hydrogen containing functional groups shown in the FTIR analysis reveal that hydrogen bonding of tetracycline to the biochar surface is also possible. The $\mathrm{OH}$ groups present on the tetracycline can interact with the oxygen containing functional groups present in the biochar (Shen et al., 2020).

Tetracycline is known to exist as different species at different levels of $\mathrm{pH}$. These include $\mathrm{H}_{4} \mathrm{TC}^{+}$ under acidic conditions up to $\mathrm{pH} 7.2, \mathrm{H}_{3} \mathrm{TC}$ predominant under weakly acidic conditions, but still present in basic conditions up to $\mathrm{pH} 10$, and $\mathrm{H}_{2} \mathrm{TC}^{-}$under basic conditions, with the $\mathrm{HTC}^{2-}$ species favoured by strong basic conditions above pH 8 (Caminati and Puggelli, 2011). Under acidic conditions, biochar has a less negative, or even positive surface charge (Tan et al., 2020). Therefore, under acidic conditions, the $\mathrm{H}_{4} \mathrm{TC}^{+}$species could be less attracted to the biochar surface where the negative surface charge has been decreased or reversed by the adsorption of $\mathrm{H}^{+}$ions to the biochar surface. The opposite is true at higher $\mathrm{pH}$, where hydrogen ions are drawn off of the biochar surface, causing the biochar to have a negatively charged surface due to deprotonated functional groups. Therefore, neutral pH could be highly beneficial for tetracycline adsorption to biochars where the predominant tetracycline species is $\mathrm{H}_{3}$ TC (Zhang et al., 2020). Indeed, other similar studies that used crushed shrimp shell and magnetic biochar as adsorbents found that $\mathrm{pH} 7$ was optimal for tetracycline adsorption since the inhibitory electrostatic repulsion under high and low $\mathrm{pH}$ conditions were reduced. This is due to Tetracycline predominantly existing in its neutral state at $\mathrm{pH} 7$, in addition to the adsorbent surface being neither highly protonated or deprotonated under conditions of neutral pH (Chang et al., 2020; Li et al., 2019). It can therefore be suggested that hydrogen bonding and $\pi-\pi$ EDA interactions are two key adsorption mechanisms under the applied experimental conditions, where these are less dependent on conditions of $\mathrm{pH}$ compared with 
electrostatic interactions between the biochar and tetracycline. The electrostatic interactions between the biochar and tetracycline molecules are limited at the experimental $\mathrm{pH}$ used.

\subsection{Comparison of adsorption performance with literature}

Table 3 shows literature results for the biochars adsorption capacity for tetracycline. Higher pyrolysis temperatures favour tetracycline adsorption. However, the oil and gas by-products generated at these temperatures contain larger amounts of PAHs which can be harmful to humans and the environment ( $\mathrm{Hu}$ et al., 2020). Furthermore, the toxicity of the PAHs produced above $300{ }^{\circ} \mathrm{C}$ is typically higher than the respective $\mathrm{PAHs}$ observed at pyrolysis temperatures of $300{ }^{\circ} \mathrm{C}$ (Devi and Saroha, 2015). It is arguable therefore, that pyrolysis systems intended for use by less skilled operators should operate at pyrolysis temperatures below $400{ }^{\circ} \mathrm{C}$. The latter reduces the operator's risk of exposure to harmful PAHs and dioxins. The pyrolysis device used in this study was a pilot scale pyrolysis chamber, whereas the studies reported in literature use experimental scale pyrolysis processes; these typically make use of tube furnaces under nitrogen atmosphere. The adsorption data reveal that biochar produced from agricultural waste can be used as an adsorbent to reduce the concentration of antibiotics in aquatic environments. This could aid in decreasing the proliferation of ARGs in aquatic bacteria. Moreover, the biochar produced in this study is comparable and in some cases more efficient than biochar in other studies for the removal of tetracycline from aqueous waste streams (Jang and Kan, 2019a; Nguyen et al., 2019; Zhang et al., 2019).

In addition, the biochar used in this study was obtained from the pyrolysis of mixed waste including food, and plant trimmings, meanwhile the studies in the table used more specific precursor material. This indicates that an agricultural enterprise such as a farm, that produces mixed waste streams could produce adsorbents of a similar quality using a heat pipe based 
reactor. This would, whilst reduce the waste footprint of such an enterprise, without needing a feedstock sorting process. 
Table 3 - The production parameters of some biochars, with experimental conditions and tetracycline adsorption for comparison with this study

\begin{tabular}{|c|c|c|c|c|c|c|c|}
\hline $\begin{array}{l}\text { Feed } \\
\text { stock }\end{array}$ & $\begin{array}{l}\text { Pyrolysis } \\
\text { temp. } \\
\left({ }^{\circ} \mathrm{C}\right)\end{array}$ & Activation/modification & $\begin{array}{l}\text { Initial } \\
\text { conc. } \\
\text { (mg/l) }\end{array}$ & $\begin{array}{l}\text { Biochar } \\
\text { dosage } \\
(\mathrm{g} / \mathrm{l})\end{array}$ & pH & $\begin{array}{l}\text { Tetracycline } \\
\text { adsorption } \\
(\mathrm{mg} / \mathrm{g})\end{array}$ & Source \\
\hline
\end{tabular}

\begin{tabular}{|c|c|c|c|c|c|c|}
\hline \multirow{3}{*}{$\begin{array}{l}\text { Auricularia } \\
\text { auricula }\end{array}$} & 300 & 10 & \multirow[t]{3}{*}{3.2} & \multirow[t]{3}{*}{7} & 2.020 & \multirow[t]{3}{*}{ (Dai et al., 2020) } \\
\hline & 500 & 10 & & & 3.270 & \\
\hline & 700 & 10 & & & 4.130 & \\
\hline Bamboo & 700 & 20 & 1 & $<7$ & 2.500 & (Zhao et al., 2019) \\
\hline
\end{tabular}

\begin{tabular}{|c|c|c|c|c|c|c|c|}
\hline \multirow[t]{2}{*}{ Bamboo } & \multirow[t]{2}{*}{700} & $\begin{array}{l}2 \mathrm{~g} \text { Silica ball milled with biomass, followed by } \mathrm{CaCl}_{2} \\
\text { impregnation prior to pyrolysis }\end{array}$ & 20 & 1 & $<7$ & 8.000 & \\
\hline & & $\begin{array}{l}8 \mathrm{~g} \text { Silica ball milled with biomass, followed by } \mathrm{CaCl}_{2} \\
\text { impregnation prior to pyrolysis }\end{array}$ & 20 & 1 & $<7$ & 22.50 & \\
\hline $\begin{array}{l}\text { Maple } \\
\text { leaves }\end{array}$ & 350 & & 100 & 0.1 & 6 & 40.30 & (Kim et al., 2020) \\
\hline $\begin{array}{l}\text { Maple } \\
\text { leaves }\end{array}$ & 750 & & 100 & 0.1 & 6 & 361.0 & \\
\hline \multirow[t]{2}{*}{ Rice husk } & $450-500$ & $\begin{array}{l}\text { Biochar mixed with } 3 \mathrm{M} \mathrm{NaOH} \text { solution at } 60-70{ }^{\circ} \mathrm{C} \text { after } \\
\text { pyrolysis, then rinsed and dried }\end{array}$ & 100 & 1 & - & 81.00 & \multirow[t]{2}{*}{ (Jing et al., 2014) } \\
\hline & & Biochar mixed with acidified methanol & 100 & 1 & - & 95.63 & \\
\hline Alfalfa & 500 & $\begin{array}{l}\text { Washed with } \mathrm{DI} \text { water for } 2 \mathrm{~h} \text {, then } 0.1 \mathrm{M} \mathrm{HCl} \text { for } 2 \mathrm{~h} \text {, then } \\
\text { washed with } \mathrm{DI} \text { water until filtrate } \mathrm{pH} \text { reaches } 7\end{array}$ & 100 & 0.1 & 5 & 289.6 & $\begin{array}{l}\text { (Jang and Kan, } \\
\text { 2019b) }\end{array}$ \\
\hline
\end{tabular}




\begin{tabular}{|c|c|c|c|c|c|c|c|}
\hline $\begin{array}{l}\text { Bermudagr } \\
\text { ass }\end{array}$ & 500 & & 100 & 0.1 & 5 & 28.96 & \\
\hline $\begin{array}{l}\text { Poplar saw } \\
\text { dust }\end{array}$ & 300 & & 100 & 1 & 5 & 6.220 & $\begin{array}{l}\text { (Huang et al., } \\
2020)\end{array}$ \\
\hline $\begin{array}{l}\text { Poplar saw } \\
\text { dust }\end{array}$ & 500 & & 100 & 1 & 5 & 14.00 & \\
\hline $\begin{array}{l}\text { Poplar saw } \\
\text { dust }\end{array}$ & 700 & & 100 & 1 & 5 & 22.21 & \\
\hline \multirow{3}{*}{$\begin{array}{l}\text { Poplar saw } \\
\text { dust }\end{array}$} & 220 & Thermal air oxidation at $300^{\circ} \mathrm{C}$ & 100 & 1 & 5 & 33.32 & \\
\hline & & Thermal air oxidation at $500^{\circ} \mathrm{C}$ & 250 & 1 & 5 & 196.7 & \\
\hline & & Thermal air oxidation at $700{ }^{\circ} \mathrm{C}$ & 100 & 1 & 5 & 60.90 & \\
\hline Food and & 300 & & 20 & 5 & 7 & 2.98 & \multirow[t]{5}{*}{ This study } \\
\hline Garden & & & 40 & 5 & 7 & 4.68 & \\
\hline \multirow[t]{3}{*}{ waste } & & & 60 & 5 & 7 & 5.78 & \\
\hline & & & 80 & 5 & 7 & 8.23 & \\
\hline & & & 100 & 5 & 7 & 9.45 & \\
\hline
\end{tabular}


The heat pipe reactor used in this study could also be installed and operated in agricultural enterprises in developing countries. Furthermore, such a system may be more easily adopted in areas of higher population density, where access to skilled labour is more likely. Pyrolysis as a process is still attainable in isolated rural communities, where traditional pyrolysis processes would serve as a substitute for the heat pipe reactor used in this study. The pyrolysis temperature in conventional processes often exceeds the pyrolysis temperatures used in this study (Tintner et al., 2020). Therefore, greater precautions for conventional pyrolysis towards the production of adsorbents in developing rural areas are required. A low temperature heat-pipe based pyrolysis reactor is shown to produce an adequate adsorbent for anti-biotics, and results in the reduced risk of exposure to hazardous PAHs and dioxins.

\section{Conclusion}

Biochar produced using a heat pipe reactor from food and plant trimmings was found to have an adsorption capacity for tetracycline of up to $9.45 \mathrm{mg} / \mathrm{g}$ under the experimental conditions. The fitting of the kinetic models followed the order Elovich>PSO>PFO, indicating that the adsorption of tetracycline is controlled by chemisorption, as well as intraparticle and liquid film diffusion. The Freundlich isotherm was shown to be the best fitting isotherm, suggesting a heterogenous adsorbent. The biochar displayed comparable tetracycline adsorption characteristics to biochar produced under similar conditions in literature. Therefore, biochar produced by a heat pipe reactor using food/organic feedstock from homes and businesses and/or agricultural waste could be used to reduce the presence of antibiotics in the environment. This adsorbent could be further modified to improve its capacity to remove tetracycline and potentially remove other antibiotics from wastewater.

\section{ACKNOWLEDGMENT}


The reported work was funded by EPSRC under Grant 1956470.

\section{References}

Alatalo, S.-M., Daneshvar, E., Kinnunen, N., Meščeriakovas, A., Thangaraj, S.K., Jänis, J., Tsang, D.C.W., Bhatnagar, A., Lähde, A., 2019. Mechanistic insight into efficient removal of tetracycline from water by Fe/graphene. Chem. Eng. J. 373, 821-830. https://doi.org/https://doi.org/10.1016/j.cej.2019.05.118

Caminati, G., Puggelli, M., 2011. Europium in phospholipid nanoscaffolds for the photophysical detection of antibiotic traces in solution. Eur. Compd. Prod. Appl. 203228.

Chang, J., Shen, Z., Hu, X., Schulman, E., Cui, C., Guo, Q., Tian, H., 2020. Adsorption of Tetracycline by Shrimp Shell Waste from Aqueous Solutions: Adsorption Isotherm, Kinetics Modeling, and Mechanism. ACS Omega 5, 3467-3477. https://doi.org/10.1021/acsomega.9b03781

Chen, J., Yu, X., Li, C., Tang, X., Sun, Y., 2020. Removal of tetracycline via the synergistic effect of biochar adsorption and enhanced activation of persulfate. Chem. Eng. J. 382, 122916. https://doi.org/https://doi.org/10.1016/j.cej.2019.122916

Chen, M., Wu, P., Huang, Z., Liu, J., Li, Y., Zhu, N., Dang, Z., Bi, Y., 2019. Environmental application of MgMn-layered double oxide for simultaneous efficient removal of tetracycline and Cd pollution: Performance and mechanism. J. Environ. Manage. 246, 164-173. https://doi.org/https://doi.org/10.1016/j.jenvman.2019.06.002

Chen, W., Wei, R., Ni, J., Yang, L., Qian, W., Yang, Y., 2018. Sorption of chlorinated hydrocarbons to biochars in aqueous environment: Effects of the amorphous carbon 
structure of biochars and the molecular properties of adsorbates. Chemosphere 210, 753-761. https://doi.org/https://doi.org/10.1016/j.chemosphere.2018.07.071

Cheng, D., Ngo, H.H., Guo, W., Chang, S.W., Nguyen, D.D., Zhang, X., Varjani, S., Liu, Y., 2020. Feasibility study on a new pomelo peel derived biochar for tetracycline antibiotics removal in swine wastewater. Sci. Total Environ. 720, 137662. https://doi.org/https://doi.org/10.1016/j.scitotenv.2020.137662

Choudhary, M., Kumar, R., Neogi, S., 2020. Activated biochar derived from Opuntia ficusindica for the efficient adsorption of malachite green dye, $\mathrm{Cu}+2$ and $\mathrm{Ni}+2$ from water. J. $\begin{array}{lll}\text { Hazard. } & \text { Mater. 392, } & 122441 .\end{array}$ https://doi.org/https://doi.org/10.1016/j.jhazmat.2020.122441

Dai, Y., Li, J., Shan, D., 2020. Adsorption of tetracycline in aqueous solution by biochar derived from waste Auricularia auricula dregs. Chemosphere 238, 124432. https://doi.org/https://doi.org/10.1016/j.chemosphere.2019.124432

Das, S., Dash, H.R., 2017. Handbook of metal-microbe interactions and bioremediation, Handbook of Metal-Microbe Interactions and Bioremediation. https://doi.org/10.1201/9781315153353

De Corato, U., 2020. Agricultural waste recycling in horticultural intensive farming systems by on-farm composting and compost-based tea application improves soil quality and plant health: A review under the perspective of a circular economy. Sci. Total Environ. 738, 139840. https://doi.org/https://doi.org/10.1016/j.scitotenv.2020.139840

Devi, P., Saroha, A.K., 2015. Effect of pyrolysis temperature on polycyclic aromatic hydrocarbons toxicity and sorption behaviour of biochars prepared by pyrolysis of paper mill effluent treatment plant sludge. Bioresour. Technol. 192, 312-320. https://doi.org/https://doi.org/10.1016/j.biortech.2015.05.084 
Elsaid, K., Sayed, E.T., Abdelkareem, M.A., Mahmoud, M.S., Ramadan, M., Olabi, A.G., 2020a. Environmental impact of emerging desalination technologies: A preliminary evaluation. $\begin{array}{lllll}\text { J. Environ. } & \text { Chem. } & \text { Eng. }\end{array}$ https://doi.org/https://doi.org/10.1016/j.jece.2020.104099

Elsaid, K., Taha Sayed, E., Yousef, B.A.A., Kamal Hussien Rabaia, M., Ali Abdelkareem, M., Olabi, A.G., 2020b. Recent progress on the utilization of waste heat for desalination: A $\begin{array}{llll}\text { review. } & \text { Energy } & \text { Convers. }\end{array}$ https://doi.org/https://doi.org/10.1016/j.enconman.2020.113105

Gómez-Pacheco, C. V, Sánchez-Polo, M., Rivera-Utrilla, J., López-Peñalver, J., 2011. Tetracycline removal from waters by integrated technologies based on ozonation and biodegradation. Chem. Eng. J. 178, 115-121. https://doi.org/https://doi.org/10.1016/j.cej.2011.10.023

Hoslett, J., Ghazal, H., Ahmad, D., Jouhara, H., 2019. Removal of copper ions from aqueous solution using low temperature biochar derived from the pyrolysis of municipal solid $\begin{array}{lllll}\text { waste. Sci. } & \text { Total } & \text { 6777-789. }\end{array}$ https://doi.org/https://doi.org/10.1016/j.scitotenv.2019.04.085

Hoslett, J., Ghazal, H., Mohamad, N., Jouhara, H., 2020. Removal of methylene blue from aqueous solutions by biochar prepared from the pyrolysis of mixed municipal discarded $\begin{array}{lllll}\text { material. } & \text { Sci. } & \text { Total } & \text { Environ. } & \text { 714, }\end{array}$ https://doi.org/https://doi.org/10.1016/j.scitotenv.2020.136832

Hu, Y., Xia, Y., Di Maio, F., Yu, F., Yu, W., 2020. Investigation of polycyclic aromatic hydrocarbons (PAHs) formed in three-phase products from the pyrolysis of various wastewater sewage sludge. J. Hazard. Mater. 389, 122045. https://doi.org/https://doi.org/10.1016/j.jhazmat.2020.122045 
Huang, H., Niu, Z., Shi, R., Tang, J., Lv, L., Wang, J., Fan, Y., 2020. Thermal oxidation activation of hydrochar for tetracycline adsorption: the role of oxygen concentration and $\begin{array}{llll}\text { temperature. } & \text { Bioresour. } & \text { Technol. } & \text { 306, }\end{array}$ https://doi.org/https://doi.org/10.1016/j.biortech.2020.123096

Jang, H.M., Kan, E., 2019a. Engineered biochar from agricultural waste for removal of tetracycline in water. Bioresour. Technol. 284, 437-447. https://doi.org/https://doi.org/10.1016/j.biortech.2019.03.131

Jang, H.M., Kan, E., 2019b. A novel hay-derived biochar for removal of tetracyclines in water. $\begin{array}{lll}\text { Bioresour. } & \text { Technol. } & \text { 274, }\end{array}$ https://doi.org/https://doi.org/10.1016/j.biortech.2018.11.081

Jang, H.M., Yoo, S., Choi, Y.-K., Park, S., Kan, E., 2018. Adsorption isotherm, kinetic modeling and mechanism of tetracycline on Pinus taeda-derived activated biochar. Bioresour. Technol. 259, 24-31. https://doi.org/https://doi.org/10.1016/j.biortech.2018.03.013 Jing, X.-R., Wang, Y.-Y., Liu, W.-J., Wang, Y.-K., Jiang, H., 2014. Enhanced adsorption performance of tetracycline in aqueous solutions by methanol-modified biochar. Chem. Eng. J. 248, 168-174. https://doi.org/https://doi.org/10.1016/j.cej.2014.03.006 Joseph, L., Jun, B.-M., Flora, J.R. V, Park, C.M., Yoon, Y., 2019. Removal of heavy metals from water sources in the developing world using low-cost materials: A review. Chemosphere 229, 142-159. https://doi.org/https://doi.org/10.1016/j.chemosphere.2019.04.198

Jouhara, H., Ahmad, D., Czajczyńska, D., Ghazal, H., Anguilano, L., Reynolds, A., Rutkowski, P., Krzyżyńska, R., Katsou, E., Simons, S., Spencer, N., 2018. Experimental investigation on the chemical characterisation of pyrolytic products of discarded food at temperatures up to $300^{\circ} \mathrm{C}$. Therm. Sci. Eng. Prog. 5, 579-588. https://doi.org/https://doi.org/10.1016/j.tsep.2018.02.010 
Kadhom, M., Albayati, N., Alalwan, H., Al-Furaiji, M., 2020. Removal of dyes by agricultural $\begin{array}{lllll}\text { waste. Sustain. } & \text { Chem. }\end{array}$ https://doi.org/https://doi.org/10.1016/j.scp.2020.100259

Kim, J.E., Bhatia, S.K., Song, H.J., Yoo, E., Jeon, H.J., Yoon, J.-Y., Yang, Y., Gurav, R., Yang, Y.-H., Kim, H.J., Choi, Y.-K., 2020. Adsorptive removal of tetracycline from aqueous solution by maple leaf-derived biochar. Bioresour. Technol. 306, 123092. https://doi.org/https://doi.org/10.1016/j.biortech.2020.123092

Kwak, J.-H., Islam, M.S., Wang, S., Messele, S.A., Naeth, M.A., El-Din, M.G., Chang, S.X., 2019. Biochar properties and lead(II) adsorption capacity depend on feedstock type, pyrolysis temperature, and steam activation. Chemosphere 231, 393-404. https://doi.org/https://doi.org/10.1016/j.chemosphere.2019.05.128

Li, G., Yuan, Q., Khan, A.A., 2019. Effect of solution $\mathrm{pH}$ on the kinetic adsorption of tetracycline by la-modified magnetic bagasse biochar. Nat. Environ. Pollut. Technol.

Li, W., Khalid, H., Zhu, Z., Zhang, R., Liu, G., Chen, C., Thorin, E., 2018. Methane production through anaerobic digestion: Participation and digestion characteristics of cellulose, hemicellulose and lignin. Appl. Energy 226, 1219-1228. https://doi.org/https://doi.org/10.1016/j.apenergy.2018.05.055

Mahmoud, M., Ramadan, M., Naher, S., Pullen, K., Baroutaji, A., Olabi, A.-G., 2020. Recent advances in district energy systems: A review. Therm. Sci. Eng. Prog. 100678. https://doi.org/https://doi.org/10.1016/j.tsep.2020.100678

Mohseni-Bandpei, A., Majlesi, M., Rafiee, M., Nojavan, S., Nowrouz, P., Zolfagharpour, H., 2019. Polycyclic aromatic hydrocarbons (PAHs) formation during the fast pyrolysis of hazardous health-care waste. Chemosphere 227, 277-288. https://doi.org/https://doi.org/10.1016/j.chemosphere.2019.04.028 
Mosaleheh, N., Sarvi, M.N., 2020. Minimizing the residual antimicrobial activity of tetracycline after adsorption into the montmorillonite: Effect of organic modification. Environ. Res. 182, 109056. https://doi.org/https://doi.org/10.1016/j.envres.2019.109056

Nguyen, V.-T., Nguyen, T.-B., Chen, C.-W., Hung, C.-M., Vo, T.-D.-H., Chang, J.-H., Dong, C.-D., 2019. Influence of pyrolysis temperature on polycyclic aromatic hydrocarbons production and tetracycline adsorption behavior of biochar derived from spent coffee ground. Bioresour. Technol. 284, 197-203. https://doi.org/https://doi.org/10.1016/j.biortech.2019.03.096

Novak, J.M., Johnson, M.G., Spokas, K.A., 2018. Concentration and Release of Phosphorus and Potassium From Lignocellulosic- and Manure-Based Biochars for Fertilizer Reuse . Front. Sustain. Food Syst. .

Olabi, A.G., 2010. The 3rd international conference on sustainable energy and environmental protection SEEP 2009 - Guest Editor's Introduction. Energy 35, 4508-4509. https://doi.org/https://doi.org/10.1016/j.energy.2010.09.053

Olabi, A.G., Wilberforce, T., Sayed, E.T., Elsaid, K., Rezk, H., Abdelkareem, M.A., 2020. Recent progress of graphene based nanomaterials in bioelectrochemical systems. Sci. Total Environ. 141225. https://doi.org/https://doi.org/10.1016/j.scitotenv.2020.141225

Oyelude, E., Awudza, J.A., Twumasi, S., 2017. Equilibrium, Kinetic and Thermodynamic Study of Removal of Eosin Yellow from Aqueous Solution Using Teak Leaf Litter Powder. Sci. Rep. 7. https://doi.org/10.1038/s41598-017-12424-1

Pan, M., Lin, X., Xie, J., Huang, X., 2017. Kinetic, equilibrium and thermodynamic studies for phosphate adsorption on aluminum hydroxide modified palygorskite nano-composites. RSC Adv. 7, 4492-4500. https://doi.org/10.1039/C6RA26802A

Sajjadi, B., Chen, W.-Y., Mattern, D.L., Hammer, N., Dorris, A., 2020. Low-temperature 
acoustic-based activation of biochar for enhanced removal of heavy metals. J. Water Process Eng. 34, 101166. https://doi.org/https://doi.org/10.1016/j.jwpe.2020.101166

Saleh, M., Assaad, F., Abdel-Salam, A.-S., Youssef, R., El-Damarawy, Y., 2018. Adsorption of Lead onto a Waste Biomaterial-Biochar. Nat. Sci. 15. https://doi.org/10.7537/marsnsj151217.16.

Shen, Q., Wang, Z., Yu, Q., Cheng, Y., Liu, Z., Zhang, T., Zhou, S., 2020. Removal of tetracycline from an aqueous solution using manganese dioxide modified biochar derived from Chinese herbal medicine residues. Environ. Res. 183, 109195. https://doi.org/https://doi.org/10.1016/j.envres.2020.109195

Strugeon, E., Tilloy, V., Ploy, M.-C., Da Re, S., 2016. The Stringent Response Promotes Antibiotic Resistance Dissemination by Regulating Integron Integrase Expression in Biofilms. MBio 7, e00868-16. https://doi.org/10.1128/mBio.00868-16

Tan, Z., Yuan, S., Hong, M., Zhang, L., Huang, Q., 2020. Mechanism of negative surface charge formation on biochar and its effect on the fixation of soil Cd. J. Hazard. Mater. 384, 121370. https://doi.org/https://doi.org/10.1016/j.jhazmat.2019.121370

Tang, L., Yu, J., Pang, Y., Zeng, G., Deng, Y., Wang, J., Ren, X., Ye, S., Peng, B., Feng, H., 2018. Sustainable efficient adsorbent: Alkali-acid modified magnetic biochar derived from sewage sludge for aqueous organic contaminant removal. Chem. Eng. J. 336, 160-169. https://doi.org/https://doi.org/10.1016/j.cej.2017.11.048

Tintner, J., Preimesberger, C., Pfeifer, C., Theiner, J., Ottner, F., Wriessnig, K., Puchberger, M., Smidt, E., 2020. Pyrolysis profile of a rectangular kiln - natural scientific investigation of a traditional charcoal production process. J. Anal. Appl. Pyrolysis 146, 104757. https://doi.org/https://doi.org/10.1016/j.jaap.2019.104757

Tran, H.N., Tomul, F., Thi Hoang Ha, N., Nguyen, D.T., Lima, E.C., Le, G.T., Chang, C.-T., Masindi, 
V., Woo, S.H., 2020. Innovative spherical biochar for pharmaceutical removal from water: Insight into adsorption mechanism. J. Hazard. Mater. 394, 122255. https://doi.org/https://doi.org/10.1016/j.jhazmat.2020.122255

Valério, A., Wang, J., Tong, S., de Souza, A.A.U., Hotza, D., Gómez González, S.Y., 2020. Synergetic Effect of Photocatalysis and Ozonation for Enhanced Tetracycline Degradation using Highly Macroporous Photocatalytic Supports. Chem. Eng. Process. Process Intensif. 107838. https://doi.org/https://doi.org/10.1016/j.cep.2020.107838

Waiapu Timothy McMillan, O., 2018. Characteristics and mechanisms of atrazine sorption to biochar for land remediation. University of Cambridge.

Wang, S., Kwak, J.-H., Islam, M.S., Naeth, M.A., Gamal El-Din, M., Chang, S.X., 2020. Biochar surface complexation and $\mathrm{Ni}(\mathrm{II}), \mathrm{Cu}(\mathrm{II})$, and $\mathrm{Cd}(\mathrm{II})$ adsorption in aqueous solutions depend on feedstock type. Sci. Total Environ. 712, 136538. https://doi.org/https://doi.org/10.1016/j.scitotenv.2020.136538

Wencewicz, T.A., 2019. Crossroads of Antibiotic Resistance and Biosynthesis. J. Mol. Biol. 431, 3370-3399. https://doi.org/https://doi.org/10.1016/j.jmb.2019.06.033

Wu, F.-C., Tseng, R.-L., Juang, R.-S., 2009. Characteristics of Elovich equation used for the analysis of adsorption kinetics in dye-chitosan systems. Chem. Eng. J. 150, 366-373. https://doi.org/https://doi.org/10.1016/j.cej.2009.01.014

Yahiat, S., Fourcade, F., Brosillon, S., Amrane, A., 2011. Removal of antibiotics by an integrated process coupling photocatalysis and biological treatment - Case of tetracycline and tylosin. Int. Biodeterior. Biodegradation 65, 997-1003. https://doi.org/https://doi.org/10.1016/j.ibiod.2011.07.009

Yan, L., Liu, Y., Zhang, Yudan, Liu, S., Wang, C., Chen, W., Liu, C., Chen, Z., Zhang, Ying, 2020. $\mathrm{ZnCl} 2$ modified biochar derived from aerobic granular sludge for developed 
microporosity and enhanced adsorption to tetracycline. Bioresour. Technol. 297, 122381. https://doi.org/https://doi.org/10.1016/j.biortech.2019.122381

Yang, X., Ng, W., Wong, B.S.E., Baeg, G.H., Wang, C.-H., Ok, Y.S., 2019. Characterization and ecotoxicological investigation of biochar produced via slow pyrolysis: Effect of feedstock composition and pyrolysis conditions. J. Hazard. Mater. 365, 178-185. https://doi.org/https://doi.org/10.1016/j.jhazmat.2018.10.047

Yu, H., Gu, L., Chen, L., Wen, H., Zhang, D., Tao, H., 2020. Activation of grapefruit derived biochar by its peel extracts and its performance for tetracycline removal. Bioresour. Technol. 316, 123971. https://doi.org/https://doi.org/10.1016/j.biortech.2020.123971

Yu, J., Tang, L., Pang, Y., Zeng, G., Wang, J., Deng, Y., Liu, Y., Feng, H., Chen, S., Ren, X., 2019. Magnetic nitrogen-doped sludge-derived biochar catalysts for persulfate activation: Internal electron transfer mechanism. Chem. Eng. J. 364, 146-159. https://doi.org/https://doi.org/10.1016/j.cej.2019.01.163

Zeng, Z., Ye, S., Wu, H., Xiao, R., Zeng, G., Liang, J., Zhang, C., Yu, J., Fang, Y., Song, B., 2019. Research on the sustainable efficacy of g-MoS2 decorated biochar nanocomposites for removing tetracycline hydrochloride from antibiotic-polluted aqueous solution. Sci. $\begin{array}{lll}\text { Total Environ. 206-217. } & \text { 648, }\end{array}$ https://doi.org/https://doi.org/10.1016/j.scitotenv.2018.08.108

Zhang, H., Lu, T., Wang, M., Jin, R., Song, Y., Zhou, Y., Qi, Z., Chen, W., 2020. Inhibitory role of citric acid in the adsorption of tetracycline onto biochars: Effects of solution $\mathrm{pH}$ and Cu2+. Colloids Surfaces A Physicochem. Eng. Asp. 595, 124731. https://doi.org/https://doi.org/10.1016/j.colsurfa.2020.124731

Zhang, P., Li, Y., Cao, Y., Han, L., 2019. Characteristics of tetracycline adsorption by cow manure biochar prepared at different pyrolysis temperatures. Bioresour. Technol. 285, 
121348. https://doi.org/https://doi.org/10.1016/j.biortech.2019.121348

Zhao, Z., Nie, T., Zhou, W., 2019. Enhanced biochar stabilities and adsorption properties for tetracycline by synthesizing silica-composited biochar. Environ. Pollut. 254, 113015. https://doi.org/https://doi.org/10.1016/j.envpol.2019.113015 